\title{
Manajemen Tenaga Kependidikan di Madrasah Aliyah
}

\author{
Dinta Hafidzi ${ }^{1}$, Olianda Adistiana ${ }^{2}$, Fahruruzi Ahmad Thobi' ${ }^{3}$ \\ Program Studi Pendidikan Agama Islam, Universitas Ahmad Dahlan, Indonesia
}

\begin{tabular}{ll}
\hline \hline Article Info & \multicolumn{1}{c}{ ABSTRACT } \\
\hline Article history: & $\begin{array}{l}\text { Education staff management is an activity to manage every individual who is } \\
\text { in the Education environment in carrying out their respective duties and } \\
\text { Received Agustus 17, 2019 } \\
\text { functions to run more effectively. The success of school / madrasah-based } \\
\text { management is largely determined by its leaders in managing the teaching staff } \\
\text { available at school / madrasas. The school principal has responsibility tasks } \\
\text { related to the management of the teaching staff which is not an easy task. In } \\
\text { addition to striving to achieve the goals of the school but also striving to } \\
\text { achieve the goals of educational staff (teachers and employees) in person. }\end{array}$ \\
Keywords: & $\begin{array}{l}\text { From the field of Administration whose role is very important in the world of } \\
\text { education. In MAN 3 BANTUL there is an activity that is related to } \\
\text { administration which is modern, systematic and makes it easy for all parties. } \\
\text { Islamic Education, Staff } \\
\text { Management }\end{array}$ \\
$\begin{array}{l}\text { At this school they use a one door service, in which all other information and } \\
\text { administrative services become very clear and valid. And this service is placed } \\
\text { in the front of the school environment after the entrance gate and in the lobby } \\
\text { in order to facilitate and make it a strategic place. }\end{array}$
\end{tabular}

This is an open access article under the CC BY-SA license.

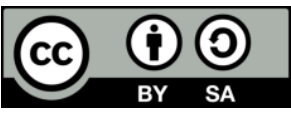

\section{Corresponding Author:}

Dinta Hafidzi

Prodi Pendidikan Agama Islam, Universitas Ahmad Dahlan Yogyakarta

Email: dinta.hafidzi24@gmail.com

\section{PENDAHULUAN}

Administrasi ketatausahaan merupakan sub sistem organisasi, dalam hal ini adalah organisasi sekolah. Kegiatan utamanya adalah mengurus segala bentuk administrasi sekolah, mulai dari surat-menyurat sampai dengan inventaris barang. Bila dilihat dari pengertian diatas maka tata usaha tidak hanya menyangkut suratmenyurat saja tetapi juga menyangkut semua bahan keterangan dan informasi yang berwujud warkat. Ketatausahaan menjadi penting karena dapat membantu dan mempermudah sub sistem yang lain seperti bagian kesiswaan, kurikulum, administrasi personel, dan lainnya. Dalam hal ini ada istilah yang disebut dengan mekanisme bantu artinya kegiatan ketatausahaan sekolah dapat dipergunakan untuk membantu pimpinan sekolah (kepala sekolah) dalam mengambil keputusan, sehingga dapat memperlancar dan meningkatkan efektivitas dan efesiensi proses administrasi, dengan data yang diperlukan. Bila administrasi ketatausahaan berjalan dengan baik maka kegiatan yang menyangkut pembelajaran dan tujuan pembelajaran dapat berjalan dengan baik pula.

Untuk itu, diperlukan staf tata usaha yang profesional dan kompeten di bidangnya. Di Madrasah Aliyah Negri 3 Bantul di bagian ketatausahaan memiliki tugas yang sama seperti pada umumnya yaitu menangani administrasi dan kerumah tanggaan. Dan terdapat beberapa bidang dibawahnya yang dinaungi dan bertanggung jawab kepada Kepala Tata Usahanya. Sistem kerja atau pelaksanaan teknisnya di sekolah ini menggunakan Pelayanan Terpadu Satu Pintu (PTSP) yang menghubungkan antara satu sama lain baik guru maupun pegawai. Sehingga hal tersebut sangat efektif dan efisien dalam pelaksanaan dan penerapannya yang memudahkan kinerja dari setiap elemen yang ada disekolah.

\section{METODE}

Penelitian ini dilakukan dengan menggunkan metode kualitatif yang menyediakan data dan informasi serta segala kebutuhan yang harus disiapkan sebelum terjun ke lapangan. Kami melakukan observasi dan wawancara di MAN 3 BANTUL untuk memenuhi kelengkapan data yang ingin kami ketahui. Peneliti 
menyiapkan beberapa pertanyaan yang sudah kami susun dan digunakan untuk mewawancarai kepala Tata Usaha sekolah terkait.

\section{HASIL DAN PEMBAHASAN}

\section{Pengertian Tenaga Kependidikan}

Dalam Undang-Undang Nomor 20 Tahun 2003 tentang Sistem Pendidikan Nasional pasal 39 ayat 1 dan 2 dinyatakan bahwa : "tenaga pendidikan bertugas melaksanakan administrasi, pengelolaan, pengembangan, pengawasan dan pelayanan teknis untuk menunjang proses pendidikan dalam satuan pendidikan." Dalam ketentuan umum pasal 1 butir 5 dan 6 dinyatakan bahwa tenaga kependidikan adalah anggota masyarakat yang mengabdikan diri dan diangkat untuk menunjang penyelenggaraan pendidikan. Dalam penjelasan atas pasal 39 ayat 1 dinyatakan bahwa tenaga kependidikan meliputi 1) Pengelola satuan Pendidikan; 2) Pemilik; 3) Pamong belajar; 4) Pengawas; 5) Peneliti; 6) Pengembang; 7) pustakawan; 8) Laboran; dan 9) Teknisi Sumber belajar

Manajemen tenaga kependidikan atau manajemen personalia pendidikan adalah kegiatan mengelola personal pendidikan dalam melaksankan tugas-tugas sesuai dengan tugas dan fungsinya agar berjalan dengan efektif. Dan dapat didefinisikan pula sebagai kegiatan menggerakkan orang lain untuk mencapai tujuan pendidikan. Manajemen tenaga kependidikan atau manajemen personalia bertujuan untuk mendayagunakan tenaga kependidikan secara efektif dan efisien untuk mencapai hasil yang optimal (Mulyasa, 2004). Manajemen personalia menganggap bahwa karyawan itu sebagai salah satu faktor produksi yang harus dimanfaatkan secara produktif atau lebih menekankan pada sistem dan prosedur (Muniroh, dkk, 2017).

\section{Pengertian Tata Usaha}

Tata usaha adalah bagian dari unit pelaksana teknis penyelenggaraan system adminitrasi dan informasi pendidikan disekolah. Pegawai atau orang yang menangani bagian administrasi dan kerumah tanggan. Tata usaha adalah kegiatan administrasi pendidikan yang mengelola pencatatan, pengumpulan, penyimpanan data, dan dokumen yang dapat dipergunakan untuk membantu pimpinan dalam pengambilan keputusan, urusan surat menyurat serta laporan mengenai kegiatan sekolah tersebut (Rahmati, 2017).

\section{Tugas-Tugas Tata Usaha}

Urusan ketatausahaan sekolah adalah bagian dari unit pelaksana teknis penyelenggara sistemadministrasi dan informasi pendidikan di sekolah/ madrasah (Permendiknas Nomor 24 Tahun 2008). Tugas tata usaha secara umum yaitu:

- Menerima, yaitu kegiatan-kegiatan mencari data mengusahakan tersedianya segala keterangan yang tadinya belum ada atau berserakan dimana-mana sehingga siap untuk dipergunakan bilamana diperlukan.

- Mencatat, yaitu kegiatan yang membutuhkan dengan berbagai peralatan tulis yang dapat dibaca, dikirim, dan disimpan. Dalam perkembangan teknologi modern maka dapat termasuk alat-alat perekam suara.

- Mengelola, yaitu bermacam kegiatan mengerjakan keterangan-keterangan dengan maksud menyajikan dalam bentuk yang lebih berguna.

- Menggandakan, yaitu kegiatan memperbanyak dengan berbagaicara dan alat sebanyak jumlah yang diperlukan.

- Mengirim, yaitu kegiatan menyampaikan dengan berbagaicara dan alat dari berbagai satu pihak kepada pihak yang lain.

- Menyimpan, yaitu kegiatan menaruh dengan berbagai cara dan alat ditempat yang aman.

- Menyusun program kerja ketatausahaan atau administrasi kelancaran (bulanan,triwulan, semesteran, dan tahunan) dalam rangka ketatausahaan/ administrasi;

- Melaksanakan kegiatan pengelolaan keuangan/dana, sarana, administrasi ketatausahaan, kepegawaian dan statistic sekolah, sesuai dengan petunjuk atau pedoman dan peraturan yang berlaku untuk mencapai tujuan pelayanan administrasi yang baik.

- Mengelola surat menyurat, inventarisasi, dokumentasi, atau agenda, pembukuan keuangan, administrasi kepegawaian, dan saran; mengatur dan mendokumentasi presensi pegawai, penyajian data statistik, pembuatan laporan rutin atau isedental, dan menghimpun data administrasi sekolah.

Selain itu, tugas pokok dan fungsi tenaga administrasi sekolah dibagi menjadi sembilan tugas pokok, 
antara lain :

- Tugas Pokok urusan administrasi

- Tugas pokok bendaharawan sekolah

- Tugas pokok urusan inventarisasi dan perlengkapan

- Tugas pokok administrasi kepegawaian

- Tugas pokok urusan administrasi kesiswaan

- Tugas pokok urusan administrasi persuratan

- Tugas pokok pengelolaan perpustakaan

- Tugas pokok administrasi pengelola labolatorium

- Tugas pokok pembantu / penjaga sekolah

Di samping tugas-tugas umum sebagaimana disebutkan di atas, Tata USaha Sekolah/ Madrasah juga memiliki tugas khusus di antaranya:

Administrasi Kepegawaian

Pada bagian ini, Tata Usaha memiliki peranan sebagai berikut:

- Melaksanakan prosedur dan mekanisme kepegawaian

- Merencanakan kebutuhan pegawaai

- Menilai dan membina staf

- Mengisi buku induk pegawai

- Menyusun daftar urut kepangkatan

- Menerbitkan surat tugas/keputusan

- Menyusun data dan statistic kepegawaian

- Menyusun arsip dan file pegawai

- Mengelola daftar hadir pegawai

\section{Administrasi Keuangan:}

Aspek ini dalam pelaksanaanya dilaksanakan oleh Perangkat bendahara yang bertanggung jawab kepada kepala tata usaha. Di antara tugas pokoknya yaitu melaksanakan administrasi keuangan sekolah; meliputi keuangan rutin/ dana komite sekolah; menyimpan dokumen, rekening giro/ bank; menerima dan melakukan pembayaran; menyimpan arsip/ dokumen dan spj keuangan; membuat laporan penggunaan keuangan; membuat laporan posisi anggaran (daya serap); dan mencatat keuangan berdasarkan sumber keuanganya pada buku kas umum, pembantu dan tabelaris.

\section{Administrasi Sarana Dan Prasarana}

Tugas pokok pada bagian ini adalah merencanakan kebutuhan dan mengelola sarana prasarana terkait dengan rincian seperti menyusun daftar kebutuhan sarana dan prasarana; mencatat dan menginventarisir sarana; menyimpan dokumen kepemilikan; dan membuat daftar inventarisasi ruang.

\section{Administrasi Kehumasan}

Dalam hal administrasi kehumasan, tenaga kenendidikan melaksanakan hubungan sekolah dan masyarakat dengan rincian tugas seperti membantu proses kegiatan komite; menjalin kerjasama dengan pemerintah dan lembaga masyarakat serta keterlibatan pemangku kepentingan (stakeholders); mencatat dan mendokumentasikan proses kegiatan kehumasan; dan mempromosikan sekolah/ madarsah dan mengkoordinasikan penelusuran tamatan.

\section{Administrasi Persuratan dan Kearsipan}

Tugas yang diemban dalam hal ini adalah melaksanakan fungsi-fungsi kesekretariatan di bidang tata persuratan dan kearsipan, seperti mengelola surat masuk dan keluar; menggandakan surat/ tikrey; mengelola buku ekspedisi persuratan; dan memelihara dan menata kearsipan dan dokumen.

\section{Administrasi Kesiswaan}

Tenaga kependidikan juga memiliki fungsi dalam proses administrasi kesiswaan dengan rincian tugas yakni membuat daftar nomor induk siswa; menyusun daftar keadaan siswa; membuat usulan peserta ujian; menginventarisir daftar lulusan; menyimpan daftar kumpulan nilai (leger); menginventarisir pendaftaran siswa baru; dan mengisipapan data keadaan siswa.

\section{Administrasi Layanan Khusus}


Pada aspek ini, tenaga kependidikan melaksanakan fungsi koordinator layanan khusus tugas-tugas seperti koordinator petugas layanan khusus sebagai penjaga, tukang kebun, petugas kebersihan, pesuruh, dan pengemudi; serta membantu program layanan khusus; UKS, bimbingan konseling, laboratorium/bengkel dan perpustakaan.

\section{Teknologi Informasi dan Komunikasi}

Dalam urusan teknologi informasi dan komunikasi, koordinator layanan data dan informasi memiliki rincian tugas yaitu mengakses dan mengelola data; mendokumentasikan administrasi; dan menginformasikan serta mempromosikan. Adapun tugas pokok dan fungsi kepala tata usaha sekolah menurut keputusan Dirjen Dikdasmen No. 260 dan 261 Tahun 1996, yaitu terdiri dari menyusun program kerja tata usaha sekolah; pengelolaan keuangan sekolah; pengurusan administrasi ketenagaan dan siswa; pembinaan dan pengembangan karir pegawai tata usaha sekolah; penyusunan dan administrasi perlengkapan sekolah; penyusunan adanya penyajian data/statistic sekolah; mengkoordinasikan dan melaksanakan $7 \mathrm{~K}$; dan penyusunan laporan pelaksanaan kegiatan pengurusan ketatausahaan secara berkala.

\section{Struktur Organisasi}

Organisasi Pusat Data dan Informasi terdiri dari 2 (dua) Bidang, 1 (satu) Bagian dan 1 (satu) Kelompok Jabatan Fungsional, yaitu:

\section{Bidang Pengembangan Teknologi Informasi dan Infrastruktur}

Bidang Pengembangan Teknologi Informasi dan Infrastruktur mempunyai tugas yaitu menyelenggarakan pengembangan, penerapan dan pengelolaan system informasi manajemen, pengembangan, pengelolaan dan pengamanan infrastruktur serta system jaringan komunikasi dan data teknis di lingkungan Sekretariat. Dalam melaksanakan tugas, bidang pengembangan teknologi informasi dan infrastruktur menyelenggarakan fungsi pengembangan dan penerapan system informasi manajemen di lingkungan sekretariat; pengembangan, pengelolaan dan pengamanan infrastruktur serta system jaringan komunikasi dan data teknis di lingkungan secretariat; pengembangan, penerapan dan pengelolaan aplikasi system informasi di lingkungan sekretariat. bidang pengembangan teknologi informasi dan infrastruktur terdiri dari: Sub Bidang PengembanganTeknologi Informasi dan Sub Bidang Infrastruktur.

\section{Bidang Pengelolaan Data dan Sistem Informasi}

Bidang Pengelolaan Data dan Sistem Informasi mempunyai tugas melaksanakan pengelolaan data dan informasi penyelenggaraan pemerintahan, peraturan perundang-undangan, persidangan dan kepegawaian serta data dan informasi lainnya terkait dengan pelaksanaan tugas Sekretariat dan penyebarluasan data dan informasi melalui jaringan komunikasi di lingkungan Sekretariat, sertapengelolaan website Sekretariat. Dalam melaksanakan tugas, Bidang Pengelolaan Data dan Sistem Informasi menyelenggarakan fungsi :

- Pengumpulan dan pengelolaan data dan informasi penyelenggaraan pemerintahan, peraturan perundang-undangan, persidangan dan kepegawaian serta data dan informasi lainnya terkait dengan pelaksanaan tugas Sekretariat.

- Penyimpanan, pengolahan dan penyajian data dan informasi penyelenggaraan pemerintahan, peraturan perundang-undangan, persidangan dan kepegawaian serta data dan informasi lainnya terkait dengan pelaksanaan tugas Sekretariat.

- Pembinaan pemanfaatan system informasi dan teknologi informasi.

- Pengembangan dan pengelolaan website Sekretariat. Bidang Pengelolaan Data dan Sistem Informasi terdiri dari Sub Bidang Pengelolaan Data dan Informasi dan Sub Bidang Pengelolaan Sistem Informasi.

\section{Bagian Tata Usaha}

Bagian Tata Usaha Bagian Tata Usaha mempunyai tugas melaksanakan perencanaan dan program kerja, urusan ketatausahaan dan keuangan, serta pelaporan dan evaluasi pelaksanaan tugas di lingkungan Pusat Data dan Informasi, pemberian dukungan pelayanan teknis dan administrasi pengelolaan arsip, dokumentasi dan perpustakaan di lingkunganSekretariat. Dalam melaksanakan tugas, bagian Tata Usaha menyelenggarakan fungsi Penyusunan rencana kerja dan anggaran pusat data dan informasi; pelaksanaan urusan ketatausahaan dan keuangan di lingkungan pusat data dan informasi; pelaksanaan evaluasi dan penyusunan laporan pelaksanaantugas pusat data dan informasi; pelaksanaan pendokumentasian, penyimpanan, pengolahan, pemeliharaan serta penyusutan arsip dan dokumen peraturan perundangundangan, persidangan, dan kepegawaian serta arsip dan dokumen lainnya di lingkungan sekretariat; pelayanan penggunaan arsip dan dokumen peraturan perundang-undangan, persidangan dan kepegawaian 
serta arsip dan dokumen lainnya; penyelenggaraan dan pelayanan perpustakaan di lingkungan sekretariat; dan pemeliharaan dan pengembangan bahan-bahan pustaka di lingkungan sekretariat. bagian tata usaha terdiri dari: Sub Bagian Umum, Sub Bagian Arsip dan Dokumentasi, dan Sub Bidang Perpustakaan

\section{Peran dan Fungsi tata usaha}

Peran TU dalam suatu organisasi secara garis besar mempunyai tiga tugas pokok sebagi berikut ini:

- Melayani pelaksanan pekerjaan-pekerjaan operatif untuk mencapai tujuan organisasi

- Menyediakan keterangan-keterangan bagi puncak pimpinan organisasi itu sebagai dasar untuk membuat keputusan atau melakukan tindakan yang tepat.

- Membangun kelancaran perkembangan organisasi sebagai suatu keseluruhan.

- Berdasarkan peran TU tersebut, maka dapat disimpulkan bahwa peran TU dalam organisasi/ lembaga bersifat menyeluruh dari tingkat bawah sampai dengan tingkat atasan. Dengan demikian implementasi TU dalam suatu organisasi/ lembaga menyangkut 3 ciri utama berikut:

- Bersifat pelayanaan yang perlu diterapkan secara prima.

- Bersifat menyebar kesegenap bagian dalam organisasi/ lembaga.

- Dilaksanakan oleh semua pihak dalam organisasi/ lembaga.

Little Field dan Rachel (dalam The Liang Gie,1998) menambahkan ciri-ciri khusus dari TU di antaranya perkerjaan mental biasanya menuntut tugas-tugas yang sukar diukur; keragaman pekerjaan yang lebih besar menurut kasusnya; perkerjaan kecil yang banyak tetapi memerlukan tugas-tugas bervolume rendah untuk menetapkan standarnya; dan ketidakberaturan dari alur perkerjaan dari kebanyakan pekerjaan kantor. Suatu hal yang perlu diingat adalah bahwa TU tidak dapat berjalan atau terlaksana dengan sendirinya, meskipun mempunyai peran yang penting dalam suatu organisasi. Orang-orang yang bekerja dalam bidang TU perlu didukung dari pimpinan, sarana dan prasarana, serta factor lainnya dalam menyelesaikan tugas-tugasnya. Semua pekerjaan perkantoran perlu direncanakan, diatur, diarahkan, dan disempurnakan oleh pejabat pimpinan yang memiliki tugas menejmen.

Tugas pokok dan fungsi bagian TU perlu ditingkatkan karna memiliki peran yang sangat penting dalam pengembangan suatu organisasi. Tugas pokok bagian TU tersebut dapat dirincikan seperti melaksanakan uraian TU, rumah tangga, perlengkapan, kepegawaian dan keuangan. Pelaksaan urusan TU, pelaksaan urusan rumah tangga, perlengkapan pelaksanaan urusan kepegawaian dan pengelola keuangan. Pendapat lain tentang tugas pokok bagian TU adalah melaksanakan urusan kepegawaian, keuangan, persuratan, kearsipan, keperlengkapan, dan rumah tanggan. Berdasarkan uraian tentang tugas utama dan fungsi bagian yang diterima di atas, dapat disimpulkan dari bagian yang cukup penting dalam suatu organisasi. Urusan kepegawaian dan keuangan akan menjadi kacau jika tidak diminta oleh orang-orang tertentu (pegawai TU bagian kepegawaian dan keuangan) Masalah kepegawaian dan keuangan yang penting dalam menunjang keberlangsungan hidup suatu organisası sangat perlu dilakukan oleh orang-orang tertentu (pegawai TU bagian kepegawaian dan keuangan) kegiatan surat-menyurat, kearsipan, perlengkapan dan kegiatan TU yang lain juga dibutuhkan oleh organisasi dalam mencapai tujuannya.

\section{Faktor-Faktor Pendukung dan Penghambat Optimalisasi Kepegawaian}

Terdapat beberapa faktor yang menjadi pendukung dan penghambat pelaksanaan penggerakan oleh kepala dalam upaya mewujudkan visi dan misi organisasi di Sekolah yang antara lain faktor pendukungnya adalah sebagai berikut:

- Ketersediaan pegawai yang memadai untuk memahami visi dan misi sekolah sehingga antara keinginan kepala sekolah dan anggota organisasi dapat diwujudkan.

- Adanya sebagian anggota organisasi yang menerima dengan baik setiap kepala sekolah memberikan informasi tentang tujuan organisasi.

- Anggota organisasi sudah mendukung tercapainya tujuan organisasi hal ini dilakukan oleh anggota organisasi untuk cepat tanggap dalam melaksanakan kegiatan.

- Anggota organisasi sudah memiliki kesadaran dalam mencapai tujuan organisasi hal ini dibuktikan dengan keikutsertaanya dalam melaksanakan tujuan organisasi dengan baik sehingga anggota organisasi telah berperan aktif dalam kegiatan perencanaan sehingga dapat mengetahui dan memahami tujuan organisasi.

- Adanya keinginan sebagian anggota organisasi dalam mencapai tujuan organisasi hal ini terlihat dari adanya pegawai yang aktif melaksanakan berbagai program yang telah direncanakan sekolah karena pegawai dapat menerima filsafat yang dianut pimpinan dalam mengelola organisasi sehingga tujuan organisasi dapat dicapai dengan optimal.

- Adanya pegawai yang dapat menerima penjelasan yang disampaikan oleh kepala sekolah terkait 
kegiatan-kegiatan organisasi yang perlu mendapatkan dukungan semua anggota organisasi.

- Masih adanya pegawai yang mendukung upaya pimpinan dalam mencapai tujuan organisasi karena pimpinan selalu memberikan pengertian terkait posisi pegawai dalam organisasi sehingga pegawai yang memahami struktur organisasi bekerja sesuai dengan struktur organisasi yang ada di sekolah.

- Sedangkan faktor penghambat pelaksanaan penggerakan oleh kepala sekolah dalam upaya mewujudkan visi dan misi organisasi antara lain adalah sebagai berikut :

- Adanya pegawai yang belum memiliki kesadaran dalam melaksanakan tugasnya dengan baik sehingga tujuan organisasi kurang mendapatkan dukungan dari semua anggota organisasi.

- Adanya pegawai yang kurang memiliki kesadaran dalam melaksanakan setiap tugas dan tanggung jawabnya dalam bekerja sehingga tujuan organisasi belum dapat dicapai secara optimal.

- Kurangnya kepala sekolah yang secara terbuka menjelaskan harapan-harapannya dalam mencapai tujuan organisasi serta kepala sekolah yang kurang mengajak peran aktif semua anggota organisasi untuk mencapai tujuan sekolah.

- Kurangnya kepala sekolah dalam menjelaskan kebijakan yang akan dilaksanakan sehingga pegawai kurang mendapatkan bimbingan dalam menyelesaikan pekerjaan

- Kurangnya pegawai dalam memahami struktur organisasi yang ada di sekolah sehingga pegawai dalam melaksanakan pekerjaannya kurang sesuai dengan tugas dan fungsinya di dalam organisasi

- Kurangnya pegawai yang memahami perannya didalam organisasi hal ini disebabkan oleh pegawai kurang memberikan penjelasan kepada pegawai tentang tugas dan fungsinya di dalam organisasi.

- Kurangnya kerjasama yang terjalin diantara pegawai sehingga menyebabkan tujuan organisasi tidak dapat tercapai sesuai dengan yang telah ditargetkan pimpinan.

\section{Optimalisasi Kinerja Kepegawaian}

Adanya upaya-upaya yang dilakukan untuk mengatasi hambatan yang dihadapi dalam pelaksanaan penggerakan oleh kepala dalam upaya mewujudkan visi dan misi organisasi di Sekolah antara lain sebagai berikut:

- Meningkatkan kesadaran pegawai dalam melaksanakan tugasnya dengan baik sehingga tujuan organisasi mendapatkan dukungan dari semua anggota organisasi hal ini dilakukan oleh kepala sekolah dengan memberikan pengarahan secara rutin kepada pegawai.

- Kepala sekolah mengupayakan memberikan bimbingan kepada pegawai sehingga dapat melaksanakan setiap tugas dan tanggung jawabnya dalam bekerja sehingga tujuan organisasi dapat dicapai secara optimal.

- Kepala sekolah lebih terbuka menjelaskan harapan-harapannya dalam mencapai tujuan organisasi serta kepala sekolah mengajak peran aktif semua anggota organisasi untuk mencapai tujuan sekolah.

- Kepala sekolah menjelaskan kebijakan yang akan dilaksanakan sehingga pegawai mendapatkan bimbingan dalam menyelesaikan pekerjaan.

- Pegawai diberikan pemahaman struktur organisasi yang ada di sekolah sehingga pegawai dapat melaksanakan pekerjaanya sesuai dengan tugas dan fungsinya di dalam organisasi.

- Pegawai memahami peranannya di dalam organisasi hal ini dilakukan dengan memberikan penjelasan kepada pegawai tentang tugas dan fungsinya di dalam organisasi.

- Menjalin kerjasama yang lebih baik di antara pegawai sehingga tujuan organisasi dapat tercapai sesuai dengan yang telah ditargetkan pimpinan.

Maksud dari penggandaan dan pengadaan dalam urusan administrasi TU yaitu penggandaan atau memperbanyak arsip surat menyurat dan papper lainya untuk disimpan dan sebagai cadangan jika suatu saat dibutuhkan sebagai bahan bukti dan pegangan dan ada berkas yang hilang. Sedangkan pengadaan termasuk mengadakan suatu sarana maupun prasarana yang dibutuhkan sekolah dengan cara mengajukannya pada pemerintah seperti pengajuan proposal. Kualifikasi tenaga kependidikan yang kami dapatkan yang pertama sesuai dengan latar belakangnya, maksimal lulusan SMA dan diutamkan memiliki bidang pendidikan atau keahlian khusus misalnya dibidang komputer, administrasi, akuntansi, perpustakaan dan memiliki pengalaman kerja dan sertifikat bukti penghargaan.

Sama halnya guru yang memiliki pelatihan-pelatihan khusus seperti MGMP, KKG dan lain-lain, apakah TU juga seperti demekian? Sependek pemahaman kami dan kurang aktifnya kami bertanya kepada ibu kepala TU MAN 3 Bantul, dengan melihat kebutuhan dan kondisi yang ada sepertinya pelatihan khusus TU ada dilakukan, untuk kelancaran dan penyamaan persepsi. Sama seperti guru ada mungkin ada pelatihan dari pemerintah. Contoh yang saya temukan dilaman web motivatorpendidikan.com melaksanakan kegiatan training public speaking dan service excellent bagi tata usaha AUM PCM Cileungsi yang dilaksanakan oleh sekolah Guru Ahmad Dahlan yang merupakan sebuah program dari majelis dikdasmen PCM cileungsi. Disana mereka melatih tenaga kependidikan untuk membangun branding sekolah. 


\section{KESIMPULAN}

Manajemen tenaga kependidikan atau manajemen personalia pendidikan yaitu suatu kegiatan mengelola personal pendidikan dalam melaksankan tugas-tugasnya seusai dengan tugas dan fungsinya agar berjalan dengan efektif. Dan dapat didefinisikan pula sebagai kegiatan menggerakkan orang lain untuk mencapai tujuan pendidikan. Manajemen tenaga kependidikan atau manajemen personalia bertujuan untuk mendayagunakan tenaga kependidikan secara efektif dan efisien untuk mencapai hasil yang optimal. Tata usaha adalah kegiatan administrasi pendidikan yang mengelola pencatatan, pengumpulan, penyimpanan data, dan dokumen yang dapat dipergunakan untuk membantu pimpinan dalam pengambilan keputusan, urusan surat menyurat serta laporan mengenai kegiatan sekolah tersebut.

Berdasarkan uraian tentang tugasutama dan fungsi bagian yang diterima di atas, dapat disimpulkan bahwa tata usaha adalah satu dari bagian yang cukup penting dalam suatu organisasi. Urusan kepegawaian dan keuangan akan menjadi kacau jika tidak diminta oleh orang-orang tertentu (pegawai TU bagian kepegawaian dan keuangan) Masalah kepegawaian dan keuangan yang penting dalam menunjang keberlangsungan hidup suatu organisası sangat perlu dilakukan oleh orang-orang tertentu (pegawai TU bagian kepegawaian dan keuangan) kegiatan surat menyurat, kearsipan, perlengkapan dan kegiatan TU yang lain juga dibutuhkan oleh organisasi dalam mencapai tujuannya.

\section{REFERENSI}

Dr. E. Mulyasa, M.Pd.,.2004.Manajemen Berbasis Sekolah.Bandung: PT Remaja Rosda Karya

Dede Mae.Pelaksanaan Penggerakan Oleh Kepala Dalam Upaya Mewujudkan Visi Dan Misi Organisasi Di Sekolah Menengah Kejuruan Negeri 1 Rajadesa Kabupaten Ciamis.Komala sari Fakultas Ilmu Sosial dan Ilmu Politik Universitas Galuh Jln. R.E.Martadinata No.150 Ciamis

https://setkab.go.id/wp-content/uploads/2015/08/Laporan-Kinerja-Pusdatin-Tahun-2014.pdf

https://muhtartik.wordpress.com/2018/06/06/materi-tugas-dan-fungsi-tata-usaha-sekolah/

http://staff.uny.ac.id/sites/default/files/Pengembangan\%20TU\%20berbasis\%20Teknologi\%20Informasi.pdf

Muniroh, Jauharotul dan Muhyadi.2017.Manajemen pendidik dan tenaga kependidikan di madrasah aliyah negri kota Yogyakarta.Yogyakarta: UNY. Jurnal akuntabilitas manajemen pendidikan Vol. 5 No. 2 